\title{
Potential of crude oil-degrading bacteria to co-resist heavy metals in soil
}

\author{
S. Mustafa, A. Al-Douseri, K. Majki \& E. Al-Saleh \\ Department of Biological Sciences, Faculty of Science, \\ Kuwait University, Kuwait
}

\begin{abstract}
The toxicity and adverse effects of crude oil pollution entail a quick clean-up using available competent technologies such as bioremediation. One factor affecting the bioremediation of crude oil is the presence of stressors such as heavy metals that halt the biodegradative potentials of the indigenous microbiota resulting in prolonged bioremediation and the accumulation of toxic hydrocarbons in the environment. Thus, it was considered sensible to investigate the potentials of the indigenous microbiota to resist the inhibitory effects of heavy metals ( $\mathrm{Al}, \mathrm{Cd}, \mathrm{Co}, \mathrm{Hg}$ and $\mathrm{Ni}$ ) in soil. For this purpose, the tolerance of crude oil-degrading bacteria isolated from three different soils to heavy metals was investigated. Results demonstrated that bacteria isolated from the old crude oil-contaminated site and the recently heavy metal-contaminated construction sites that harbored high concentrations of heavy metals showed significantly $(\mathrm{P}<0.05)$ higher tolerance to heavy metals compared to those isolated from pristine soil. Furthermore, longer co-existence of bacteria with heavy metals resulted in higher bacterial potentials to tolerate the inhibitory effects of heavy metals where the majority of the isolates exhibited multiple resistances to heavy metals especially to Co and Ni. However, all heavy metals tested, in particular, Hg, Co and Ni showed lethal effects at elevated concentrations.

Keywords: pollution, crude oil-degrading bacteria, crude oil, heavy metals, bioremediation, minimum inhibitory concentration.
\end{abstract}

\section{Introduction}

Pollution of soil environment has become a serious problem in many countries; heavy metals (HM) and crude oil are two of the most abundant and potentially 
harmful pollutants [1]. They are frequently found together as co-contaminants in soils [2]. Heavy metals occur in crude oil partly as organo-metallic compounds [3]. Beside their natural occurrence, they may enter the ecological environment through anthropogenic activities [1]. These pollutants affect the activity of soil enzymes, which can be used to evaluate the soil microbial properties [2], such as Dehydrogenase and urease [1]. A variety of technologies are currently available to treat soil contaminated with hazardous materials [4]. However, bioremediation is the process whereby organic wastes are biologically degraded under controlled conditions to an innocuous state, or to levels below concentration limits [5]. Crude oil and heavy metals are often inhibitory to bioremediative processes [6]. Microorganisms including bacteria are the chief agents for the biodegradation of molecule of environmental concern [4]. Metals may inhibit pollutant biodegradation through interaction with enzymes directly involved in biodegradation or through interaction with enzymes involved in general metabolism [7]. Some bacteria sense the presence of toxic compounds and produce proteins that either convert the toxic compounds into non-harmful products, or extrude them out of the cell through methods such as extracellular precipitation, sequestration by cell envelops, intracellular accumulation, redux transformations, and membrane efflux system. Since certain metals are essential micronutrients, bacteria must adjust their resistance mechanisms to maintain appropriate levels of such compounds [8]. Bacteria which survive in such environments have developed or acquired genetic systems that counteract the effects of high metal ion concentrations [9]. Therefore, the current study was achieved to investigate the potential of the indigenous crude oil-degrading microbiota to resist the inhibitory effects of the heavy metals (Al, Cd, Co, Hg, and $\mathrm{Ni}$ ) in soil.

\section{Materials and methods}

\subsection{Collection of soil samples}

Crude oil contaminated and uncontaminated soils were collected from AlAhmadi north of Kuwait, while the garden soil was collected from Kuwait University garden. Six samples of surface soils $(10 \mathrm{~cm})$ were collected in sterile plastic containers, kept at $4^{\circ} \mathrm{C}$ and transported immediately to the lab for analyses. Soil samples were sieved $(2 \mathrm{~mm})$ and stored for two weeks at $4^{\circ} \mathrm{C}$ for stabilization [10].

\subsection{Determination of heavy metals concentration in soils}

The method of Rowell [11] was employed for the determination of the total metal content in soil. This method consists of acid digestion of soil samples followed by analysis of the digest by flame atomic absorption spectrometer (FAAS). 


\subsection{Isolation and molecular identification of the isolated crude oil-degrading bacteria}

Soil samples were sieved and (10 grams) were suspended in $40 \mathrm{ml}$ distilled water and kept overnight. Aliquots $(0.1 \mathrm{ml})$ of clear supernatant of soil suspension, indirect and its dilutions $\left(10^{-1}-10^{-4}\right)$ were spread on minimal media plates containing droplets of crude oil which are then incubated at $30^{\circ} \mathrm{C}$ for up to 24 hours, and the grown crude oil-degrading bacterial colonies (CODB) were isolated [12]. Bacterial genomic DNA was extracted, purified, quantified and used for the amplification of the 16S rDNA gene, followed by DNA sequencing and Sequencing Analysis v5.2 Software (Applied Bisystem, USA) was used to analyze the sequences that were compared to other sequences in the GeneBank database using BLAST [13].

\subsection{Effect of heavy metals on the growth of isolated bacteria}

The potential inhibitory effects of heavy metals (aluminum, cadmium, cobalt, mercury and nickel) on the growth of crude oil degrading bacteria were determined using the agar well diffusion method and optical density measurements.

\subsubsection{Agar well diffusion method}

The method of Lertcanawanichakul and Sawangnop [14] was adopted. Stocked bacterial cultures were streaked on NA plates and incubated at $30^{\circ} \mathrm{C}$ for 24 hours. Grown bacterial cultures were transferred into sterile $15 \mathrm{ml}$ Falcon tubes containing sterile $0.85 \% \mathrm{NaCl}$ solution followed by adjusting the number of bacterial cells to $1.2 \times 10^{9}$ cells $^{-1} \mathrm{ml}$ using McFarland No. 0.5 as a standard solution. Then, aliquots $(100 \mu \mathrm{l})$ of the prepared bacterial suspension were spread on the surface of NA plates, spread evenly and left for $30 \mathrm{~min}$ at room temperature. Then, wells $(10 \mathrm{~mm}$ in diameter) were punched using sterile stainless steel cork borer. Prepared metal (Al, $50 \mathrm{mg}^{-1} \mathrm{ml}$; Cd, $50 \mathrm{mg}^{-1} \mathrm{ml}$; Co, $10 \mathrm{mg}^{-1} \mathrm{ml}$; Hg, $10 \mathrm{mg}^{-1} \mathrm{ml}$; Ni, $50 \mathrm{mg}^{-1} \mathrm{ml}$ ) solutions were directly filled (50 $\left.\mu \mathrm{l}\right)$ into the wells, plates incubated at $30^{\circ} \mathrm{C}$ for 24 hours and the diameter of the inhibition zones were measured in millimeters [14].

\subsubsection{Optical density measurements of bacterial growth}

Prepared bacterial suspensions used for the well diffusion method mentioned previously were used simultaneously for the optical density measurement method. For this purpose, bacterial suspension $(50 \mu \mathrm{l})$, sterile nutrient broth $(50 \mu \mathrm{l})$ and different concentrations of metal solutions $(300 \mu \mathrm{l})$ were transferred to 100 -well Honeycomb plates. Then, plates were incubated shaking at $30^{\circ} \mathrm{C}$ for 24 hours in automated optical density reader $(600 \mathrm{~nm})$. Determined optical density values were plotted against time followed by calculation of bacterial growth rates. Bacterial growth rates were used to determine the minimum inhibitory concentrations (MIC) for tested metals. MIC values were defined as the lowest concentration of tested metals that inhibited the growth of bacteria after 24 hours of incubation. 


\section{Results}

\subsection{Heavy metal content in soils}

The concentrations of heavy metals in the crude oil-contaminated and construction sites were significantly higher than those in the pristine soil (Table 1). The highest concentration of metals was recorded for Ni followed by that of Co while the lowest concentration determined was that of $\mathrm{Cd}$ and $\mathrm{Hg}$ (Table 1). Also, the construction site harboured the highest concentrations of metals detected.

Table 1: $\quad$ Heavy metals content in soils.

\begin{tabular}{|c|c|c|c|}
\hline \multirow{2}{*}{ Heavy metal } & \multicolumn{3}{|c|}{ Heavy metal concentration (mg kg $\mathbf{~}$ ) } \\
\cline { 2 - 4 } & Crude oil-contaminated soil & Construction -site soil & Pristine soil \\
\hline Cd & 0.0142 & 0.0162 & 0.0023 \\
\hline $\mathbf{C o}$ & 2.0113 & 4.8154 & 1.6767 \\
\hline $\mathbf{H g}$ & 0.0451 & 0.0621 & 0.0236 \\
\hline $\mathbf{N i}$ & 15.293 & 38.562 & 12.445 \\
\hline $\mathbf{A l}$ & 5069 & 3967 & 1332 \\
\hline
\end{tabular}

\subsection{Identification of the isolated bacteria}

A total of 76 crude oil-degrading bacteria were isolated from all soils. Isolated bacteria were identified by sequencing of the $16 \mathrm{~S}$ rDNA gene. Four different bacteria genera were identified in the pristine soil compared to two genera identified in the crude oil-contaminated and the construction sites (Table 2).

Table 2: $\quad$ Identities of isolated crude oil-degrading bacteria.

\begin{tabular}{|l|l|c|}
\hline \multicolumn{1}{|c|}{ Soil source } & \multicolumn{1}{|c|}{ Identified bacteria } & \multicolumn{1}{|c|}{$\begin{array}{c}\text { Number of } \\
\text { bacteria found }\end{array}$} \\
\hline Construction-site & Streptomyces scabiei strain & 8 \\
\cline { 2 - 3 } & Streptomyces sp. & 8 \\
\cline { 2 - 3 } & Streptomyces bellus strain & 8 \\
\cline { 2 - 3 } & Streptomyces lavendulocolor strain & 1 \\
\cline { 2 - 3 } & Arthrobacter oxydans strain & 1 \\
\cline { 2 - 3 } & Streptomyces glomeroaurantiacus strain & 1 \\
\cline { 2 - 3 } & Streptomyces rochei strain & 1 \\
\cline { 2 - 3 } & Streptomyces tumescens strain & 1 \\
\cline { 2 - 3 } & Streptomyces ghanaensis strain & 1 \\
\hline \multirow{5}{*}{ contaminated } & \multicolumn{1}{|c|}{ Total number of isolated strains = 30 } & 11 \\
\hline \multirow{5}{*}{ Pristine soil } & Microbacterium sp. & 1 \\
\cline { 2 - 3 } & Staphylococcus sp & \\
\hline \multicolumn{1}{|c|}{ Total number of isolated strains = 12 } & 31 \\
\hline & Microbacterium sp. & 1 \\
\cline { 2 - 3 } & Bacillus pumilus strain & 1 \\
\cline { 2 - 3 } & Streptomyces pseudogriseolus & \\
\cline { 2 - 3 } & Mycobacterium goodii strain & \\
\hline
\end{tabular}




\subsection{Effect of heavy metals on the growth of isolated bacteria}

\subsubsection{Agar well diffusion method}

Bacterial tolerance to heavy metals was divided into three ranges based on the size of inhibition zone that is formed due to the reaction of the tested bacteria with heavy metals. Results showed that mercury exerted the highest toxic inhibitory effect on the growth of tested bacteria compared to other metals. On the other hand, aluminum showed the least toxic inhibitory effect (Table 3).

Table 3: Effects of heavy metals on the growth of crude oil-degrading bacteria.

\begin{tabular}{|c|c|c|c|c|c|c|c|c|c|}
\hline \multirow{3}{*}{$\begin{array}{l}\text { Number } \\
\text { of } \\
\text { bacteria } \\
\text { tested } \\
(\%)\end{array}$} & \multicolumn{9}{|c|}{ Diameter of inhibition zone (cm) } \\
\hline & \multicolumn{3}{|c|}{$\begin{array}{c}\text { Crude oil } \\
\text { contaminated soil }\end{array}$} & \multicolumn{3}{|c|}{ Construction site soil } & \multicolumn{3}{|c|}{ Pristine soil } \\
\hline & $0-0.5$ & $>0.5-2$ & $>2$ & $0-0.5$ & $>0.5-2$ & $>2$ & $0-0.5$ & $>0.5-2$ & $>2$ \\
\hline $\mathrm{Al}$ & 100 & Nil & Nil & 89.29 & 10.71 & Nil & 66 & 34 & Nil \\
\hline $\mathrm{Cd}$ & 33.33 & 50 & 16.6 & Nil & 42.86 & 57.1 & 12 & 44 & 44 \\
\hline Co & 91.67 & 8.33 & Nil & 75 & 25 & Nil & 38 & 60 & 2 \\
\hline $\mathrm{Hg}$ & 25 & 16.67 & 58.3 & Nil & 35.71 & 64.3 & 8 & 42 & 50 \\
\hline $\mathrm{Ni}$ & 91.67 & 8.33 & nil & nil & 100 & nil & 14 & 82 & 4 \\
\hline
\end{tabular}

\subsubsection{Optical density measurements of bacterial growth}

Bacterial growth rates were calculated and used to determine the minimum inhibitory concentrations (MIC) for tested metals (Tables 4, 5 and 6). Results

Table 4: $\quad$ The minimum inhibitory concentrations (MIC) of heavy metals for the crude oil- degrading bacteria isolated from the construction site soil.

\begin{tabular}{|c|c|c|c|c|c|}
\hline \multirow{2}{*}{$\begin{array}{c}\text { MIC } \\
\left(\mathbf{m g ~ m}^{-1} \mathbf{)}\right.\end{array}$} & \multicolumn{4}{|c|}{ Percentage of tested bacteria (\%) } \\
\cline { 2 - 6 } & $\mathbf{A l}$ & $\mathbf{C d}$ & $\mathbf{C o}$ & $\mathbf{~ N i}$ & $\mathbf{H g}$ \\
\hline${ }^{*}$ Nil & 10 & 25 & 35 & 45 & 15 \\
\hline 12.5 & 25 & 20 & Nil & Nil & Nil \\
\hline 5 & 10 & Nil & Nil & Nil & Nil \\
\hline 2.5 & Nil & Nil & 10 & Nil & Nil \\
\hline 0.5 & 10 & 10 & Nil & 25 & Nil \\
\hline 0.2 & Nil & 5 & 20 & 5 & Nil \\
\hline 0.1 & 5 & 10 & 5 & 5 & Nil \\
\hline 0.05 & 10 & 10 & Nil & 10 & Nil \\
\hline 0.04 & Nil & Nil & 5 & Nil & Nil \\
\hline 0.033 & 30 & 20 & Nil & 10 & Nil \\
\hline 0.02 & Nil & Nil & 25 & Nil & Nil \\
\hline 0.00667 & Nil & Nil & Nil & Nil & 5 \\
\hline 0.00333 & Nil & Nil & Nil & Nil & 20 \\
\hline 0.002 & Nil & Nil & Nil & Nil & 15 \\
\hline 0.001 & Nil & Nil & Nil & Nil & 45 \\
\hline
\end{tabular}


showed that, the highest toxicity on tested bacteria was exerted by mercury. On the contrary, aluminium demonstrated to be the least toxic metal tested. Moreover, it was observed that the different bacteria showed different levels of heavy metal resistance expressed as different MIC values. Also, some bacteria demonstrated the potential to resist the high concentrations of different metals (Table 7). In fact, the bacteria ability to resist four, three, two and a single heavy metals is shown (Table 7).

Table 5: $\quad$ The minimum inhibitory concentrations (MIC) of heavy metals for the crude oil-degrading bacteria isolated from the crude oilcontaminated soil.

\begin{tabular}{|c|c|c|c|c|c|}
\hline \multirow{2}{*}{$\begin{array}{c}\text { MIC } \\
\left(\mathbf{m g ~ m}^{\mathbf{1}} \mathbf{)}\right.\end{array}$} & \multicolumn{4}{|c|}{ Percentage of tested bacteria (\%) } \\
\cline { 2 - 6 } & Al & Cd & Co & Ni & Hg \\
\hline Nil $^{\text {Nil }}$ & 100 & 0 & 66.67 & 66.67 & 33.34 \\
\hline 12.5 & Nil & 100 & Nil & Nil & Nil \\
\hline 5 & Nil & Nil & Nil & Nil & Nil \\
\hline 2.5 & Nil & Nil & Nil & Nil & Nil \\
\hline 0.5 & Nil & Nil & Nil & 33.33 & Nil \\
\hline 0.2 & Nil & Nil & Nil & Nil & Nil \\
\hline 0.1 & Nil & Nil & 33.33 & Nil & Nil \\
\hline 0.05 & Nil & Nil & Nil & Nil & Nil \\
\hline 0.04 & Nil & Nil & Nil & Nil & Nil \\
\hline 0.033 & Nil & Nil & Nil & Nil & Nil \\
\hline 0.02 & Nil & Nil & Nil & Nil & Nil \\
\hline 0.00667 & Nil & Nil & Nil & Nil & Nil \\
\hline 0.00333 & Nil & Nil & Nil & Nil & Nil \\
\hline 0.002 & Nil & Nil & Nil & Nil & 33.33 \\
\hline 0.001 & Nil & Nil & Nil & Nil & 33.33 \\
\hline
\end{tabular}

Table 6: $\quad$ The minimum inhibitory concentrations (MIC) of heavy metals for the crude oil-degrading bacteria isolated from pristine soil.

\begin{tabular}{|c|c|c|c|c|c|}
\hline \multirow{2}{*}{$\begin{array}{c}\text { MIC } \\
\left(\mathbf{m g ~ m}^{-1} \mathbf{)}\right.\end{array}$} & \multicolumn{5}{|c|}{ Percentage of tested bacteria (\%) } \\
\cline { 2 - 6 } & Al & Cd & Co & Ni & Hg \\
\hline$*^{N i l}$ & 66.68 & 25.01 & 41.69 & 66.68 & 33.35 \\
\hline 12.5 & 16.66 & 58.33 & Nil & Nil & Nil \\
\hline 5 & Nil & Nil & Nil & Nil & Nil \\
\hline 2.5 & Nil & Nil & 16.66 & Nil & Nil \\
\hline 0.5 & Nil & 2.8 & Nil & 8.33 & Nil \\
\hline 0.2 & Nil & Nil & 16.66 & 16.66 & Nil \\
\hline 0.1 & Nil & Nil & Nil & Nil & Nil \\
\hline 0.05 & 16.66 & 8.33 & Nil & Nil & Nil \\
\hline 0.04 & Nil & 8.33 & 8.33 & Nil & Nil \\
\hline 0.033 & Nil & Nil & Nil & 8.33 & Nil \\
\hline 0.02 & Nil & Nil & 16.66 & Nil & Nil \\
\hline 0.00667 & Nil & Nil & Nil & Nil & 8.33 \\
\hline 0.00333 & Nil & Nil & Nil & Nil & 33.33 \\
\hline 0.002 & Nil & Nil & Nil & Nil & 8.33 \\
\hline 0.001 & Nil & Nil & Nil & Nil & 16.66 \\
\hline \multicolumn{7}{|l}{} & & \multicolumn{2}{l}{} \\
\hline
\end{tabular}


Table 7: Heavy metal resistance phenotypes determined for isolated crude oil-degrading bacteria.

\begin{tabular}{|c|c|c|c|c|}
\hline \multirow{2}{*}{$\begin{array}{c}\text { Phenotype } \\
\text { (metals resisted) }\end{array}$} & \multirow{2}{*}{$\begin{array}{c}\text { Number } \\
\text { of metals } \\
\text { resisted }\end{array}$} & \multicolumn{3}{|c|}{ Number of bacteria tested (\%) } \\
\hline & & $\begin{array}{c}\text { Crude oil- } \\
\text { contaminated } \\
\text { soil }\end{array}$ & $\begin{array}{l}\text { Construction } \\
\text { site soil }\end{array}$ & $\begin{array}{c}\text { Pristine } \\
\text { soil }\end{array}$ \\
\hline $\begin{array}{l}\mathrm{Al} / \mathrm{Cd} / \mathrm{Co} / \mathrm{Ni} \\
\mathrm{Cd} / \mathrm{Co} / \mathrm{Ni} / \mathrm{Hg}\end{array}$ & 4 & $\begin{array}{l}- \\
-\end{array}$ & $\begin{array}{l}5 \\
-\end{array}$ & $\begin{array}{l}8.33 \\
8.33\end{array}$ \\
\hline $\begin{array}{c}\mathrm{Al} / \mathrm{Cd} / \mathrm{Co} \\
\mathrm{Al} / \mathrm{Cd} / \mathrm{Ni} \\
\mathrm{Al} / \mathrm{Co} / \mathrm{Ni} \\
\mathrm{Cd} / \mathrm{Co} / \mathrm{Hg} \\
\mathrm{Cd} / \mathrm{Co} / \mathrm{Ni} \\
\mathrm{Cd} / \mathrm{Ni} / \mathrm{Hg} \\
\mathrm{Co} / \mathrm{Ni} / \mathrm{Hg}\end{array}$ & 3 & $\begin{array}{l}- \\
- \\
- \\
- \\
- \\
- \\
-\end{array}$ & $\begin{array}{l}- \\
5 \\
5 \\
5 \\
5 \\
- \\
-\end{array}$ & $\begin{array}{c}8.33 \\
8.33 \\
8.33 \\
8.33 \\
16.66 \\
8.33 \\
25\end{array}$ \\
\hline $\begin{array}{c}\mathrm{Al} / \mathrm{Cd} \\
\mathrm{Al} / \mathrm{Co} \\
\mathrm{Al} / \mathrm{Hg} \\
\mathrm{Al} / \mathrm{Ni} \\
\mathrm{Cd} / \mathrm{Co} \\
\mathrm{Cd} / \mathrm{Hg} \\
\mathrm{Cd} / \mathrm{Ni} \\
\mathrm{Co} / \mathrm{Hg} \\
\mathrm{Co} / \mathrm{Ni} \\
\mathrm{Ni} / \mathrm{Hg}\end{array}$ & 2 & $\begin{array}{c}66.66 \\
33.33 \\
33.33 \\
33.33 \\
- \\
- \\
- \\
- \\
- \\
-\end{array}$ & $\begin{array}{c}- \\
- \\
- \\
10 \\
5 \\
5 \\
15 \\
10 \\
25 \\
10\end{array}$ & $\begin{array}{c}25 \\
41.66 \\
16.66 \\
16.66 \\
16.66 \\
16.66 \\
16.66 \\
8.33 \\
41.6 \\
8.33\end{array}$ \\
\hline $\begin{array}{c}\mathrm{Al} \\
\mathrm{Cd} \\
\mathrm{Co} \\
\mathrm{Hg} \\
\mathrm{Ni}\end{array}$ & 1 & $\begin{array}{c}100 \\
66.66 \\
- \\
33.33 \\
33.33\end{array}$ & $\begin{array}{l}10 \\
35 \\
25 \\
49 \\
15\end{array}$ & $\begin{array}{c}66.66 \\
41.6 \\
25 \\
66.6 \\
33.33\end{array}$ \\
\hline
\end{tabular}

\section{Discussion}

Higher concentrations of heavy metals in crude oil-contaminated and construction site soils were determined compared to those in the pristine soil (Table 1). The sources of these metals could be the crude oil contaminated and the spilled materials used during construction work [1, 2, 4, 15]. In addition, diverse bacterial populations at the genus level were found in the pristine soil compared to other soils (Table 2). The lower bacterial diversity in the contaminated soils could be due the presence of stressors such as high metal and crude oil that are known to reduce bacteria diversity [16]. Also, the inhibition of bacterial growth by high concentrations of heavy metals was expected because it is documented that all metals demonstrate toxicity to living cells at certain concentration [7]. The highest toxicities demonstrated in all soil types were shown by mercury and cadmium, which usually needed, if at all, in very low concentrations thus it was expected for these metals to demonstrate higher toxicity than other metals $[7,17]$. 


\section{Conclusions}

Data analysis showed that the higher bacterial potential to tolerate heavy metals in the contaminated soils compared to the pristine soil could indicate that bacteria have the potential to develop resistance to stressors such as heavy metals found in their immediate environment. Also, the potential of crude oil-degrading bacteria to resist various concentrations of heavy metals indicated the effectiveness of the indigenous bacteria to utilize crude oil contamination in the presence of heavy metals leading to successful crude oil bioremediation. Thus, it can be concluded that no efforts are need to remediate heavy metals in the crude oil contaminated sites. However, successful biological treatment of contaminated soils is challenging due to factors such as heterogeneity of the contaminants, extreme concentrations of hydrocarbons, variable site conditions and the influence of regulatory constrains in bioremediation process. In addition, crude oil-degrading bacteria were detected in contamination-free soils which showed that, the hydrocarbon degradation trait in bacteria is common among bacteria in different soils.

\section{Acknowledgements}

We would like to thank the College of Graduate Studies, Kuwait University and sincerely acknowledge the Research Administration, Kuwait University grant number YS04/11 for supporting our work.

\section{References}

[1] Shen, G., Lu, Y., Zhou, Q., and Hong, J., Interaction of polycyclic aromatic hydrocarbons and heavy metals on soil enzyme. Chemosphere, 61, pp. 1175-1182, 2005.

[2] Shen, G., Lu, Y., and Hong, J., Combined effect of heavy metals and polycyclic aromatic hydrocarbons on urease activity in soil. Ecotoxicology and Environmental Safety, 63, pp. 474-480, 2006.

[3] Gondal, M., A., Hussain, T., Yamani, Z., H., and Baig, M., A., Detection of heavy metals in Arabian crude oil residue using laser induced breakdown spectroscopy. Talanta, 69, pp. 1072-1078, 2006.

[4] Balba, M., T., Al-Awadhi, N., and Al-Daher, R., Bioremediation of oilcontaminated soil: microbiological methods for feasibility assessment and field evaluation. Journal of Microbiological Methods, 32, pp. 155-164, 1998.

[5] Vidali, M., Bioremediation. An overview. Pure Appl. Chem., Vol. 73, No. 7, pp. 1163-1172, 2001.

[6] Stephen, J., R., Chang, Y., Macnaughton, S., J., Kowalchuk, G., A., Leung, K., T., Flemming, C., A., and White, D., C., Effect of toxic metals on Indigenous Soil $\beta$-Subgroup Proteobacterium Ammonia Oxidizer Community Structure and Protection against Toxicity by Inoculated Metal- 
Resistance Bacteria. Applied and Environmental Microbiology, Vol. 65, No. 1, pp. 95-101, 1999.

[7] Sandrin, T., and Maier, R., Impact of Metals on the Biodegradation of Organic Pollutants. Environmental Health Perspectives, Vol. 111, No. 8, pp. 1093-1101, 2003.

[8] Shetty, R., S., Deo, S., K., Shah, P., Sun, Y., Rosen, B., P., Daunert, S., Luminescence-based whole-cell-sensing systems for cadmium and lead using genetically engineered bacteria. Anal Bioanal Chem., 376, pp. 11-17, 2003.

[9] Trajanovska, S., Britz, M., L., and Bhave, M., Detection of heavy metal ion resistance genes in Gram-positive and Gram-negative bacteria isolated from a lead-contaminated site. Biodegradation, 8, pp. 113-124, 1997.

[10] AL-Saleh, E.S. and Obuekwe, C., Inhibition of hydrocarbon bioremediation by lead in a crude oil-contaminated soil. International Biodeterioration and Biodegradation, 56, pp. 1-7, 2005.

[11] Rowell D.L. (ed). Soil science, Pesticides and Metals. Publications: Addison Wesley Longman Limited, Essex, 1994.

[12] Cohen-Bazire G., Sistrom W.R., and Stainer R.Y., Kinetic studies of pigment synthesis by non-sulfur purple bacteria. Journal of Cellular Physiology, 49, pp. 25-68, 1957.

[13] Altschul, S.F., Madden, T.L., Schäffer, A.A, Zhang, J., Zhang, Z., Miller, W. and Lipman, D.J., Gapped BLAST and PSI-BLAST: a new generation of protein database search programs. Nucleic Acids Research, 25(17), pp. 3389-3402, 1997.

[14] Lertcanawanichakul, M. and Sawangnop, S., A comparison of two methods used for measuring the antagonistic activity of Bacillus species. Walailak Journal of Science and Technology, 5, pp. 161-171, 2008.

[15] Alloway, B., J., Contamination of soils in domestic gardens and allotments: a brief overview. Land Contamination and Reclamation, 12 (3), 2004.

[16] Margesin, R., and Schinner, F., Biodegradation and bioremediation of hydrocarbons in extreme environments. Appl Microbial Biotechnol, 56, pp. 650-663, 2001.

[17] Nies, D., H., Microbial heavy-metal resistance. Appl Microbial Biotechnol, 51, pp. 730-750, 1999. 